This PDF is a simplified version of the original article published in Internet Archaeology. Enlarged images, and interactive features which support this publication can be found in the original version online. All links also go to the online version.

Please cite this as: Aitchison, K. 2021 No More Polluter Pays Principle: opportunities and challenges of public benefit provision in UK development-led archaeology, Internet Archaeology 57.

\title{
No More Polluter Pays Principle: opportunities and challenges of public benefit provision in UK development-led archaeology
}

\author{
Kenneth Aitchison
}

\section{Summary}

Key to the success of archaeological projects and the provision of public benefit as a result is partnership working, whether between archaeological practices, consultants or departments within larger organisations, commercial clients or regulatory bodies. This paper presents case studies from each of these as examples of successful public benefit from development-led archaeology and outlines the move away from the 'polluter pays' principle towards a more nuanced understanding of what archaeology can provide. A Postscript refers to the Planning White Paper in the UK, which could have significant implications for how archaeology is treated within the planning system.

\section{Prelude - the 1980s}

Development-led, developer-funded and commercial archaeology are three different, related concepts. Archaeological work can be required by development without the specific developer having to pay anything (if the state covers the costs), and an obligation on the developer to pay for archaeological work does not necessarily lead to the commercialisation of archaeology, as the developer might be paying (possibly hypothecated) taxes to the government for this to be done.

The United Kingdom has a long tradition of development-led archaeology, going back to the 1970s, and of that work being funded by the developers of land where archaeological deposits lie. That work is now carried out by organisations operating on a commercial basis, with business models based on carrying out precisely this work. 
Commercial practice became the accepted norm first in the City of London, then across the rest of central London in the 1980s, and then throughout the UK in the 1990s.

The leveraging of market opportunities generated through competitive tendering in UK archaeology led to the potential for UK commercial archaeology to grow extremely rapidly from the late 1980s until 2008 (Aitchison and Edwards 2008, 17, fig. 1), and then again from 2012-2019 (Aitchison and Rocks-Macqueen 2020, 15, fig. 1, table 12). This created the opportunity for successful companies to secure work away from their immediate hinterlands, and without this archaeology would have been forever shackled by enforced, parochial territoriality.

Figure 1 shows a site being excavated by the Museum of London's Department of Urban Archaeology (DUA) in a development-led project, funded by the private developer and delivering public benefit in 1989 .

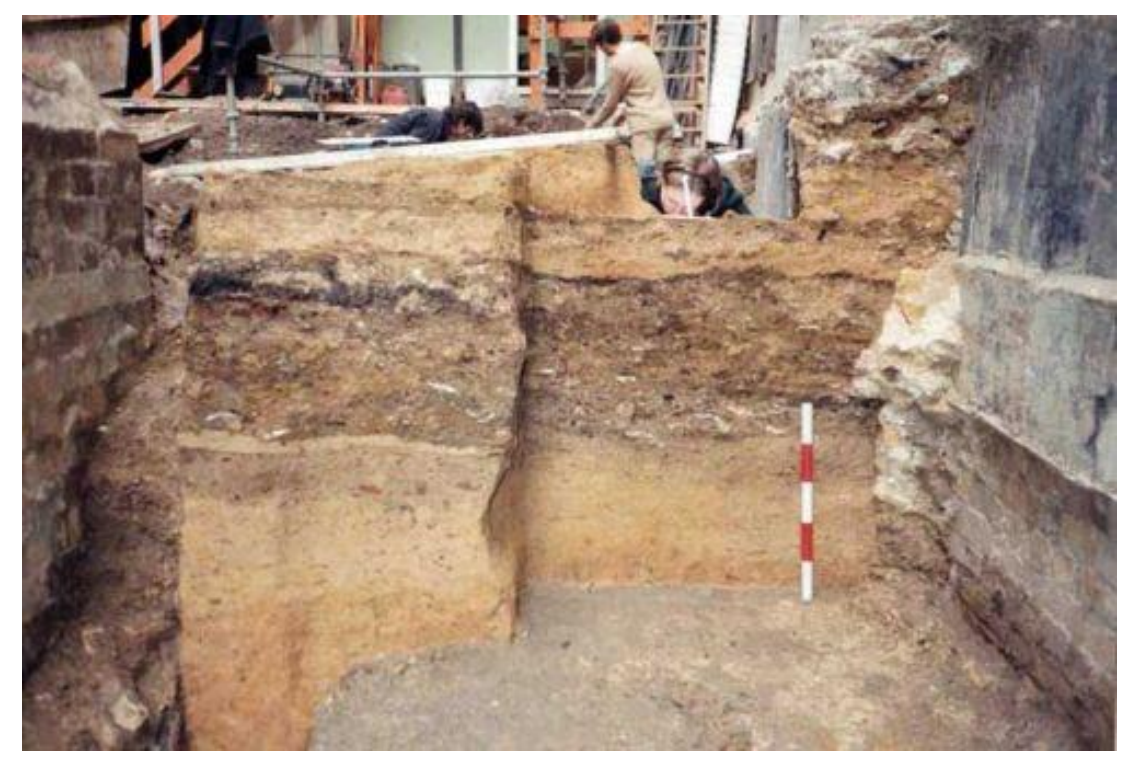

Figure 1: Stratigraphy at Leadenhall Street. Tim Neighbour, James Drummond-Murray, Alex Bayliss in background. Photo by Jerry Youle.

Location: https://www.google.com/maps/@51.5136997,-0.0855139,17z

The DUA was formed in 1973 to undertake archaeological work on sites threatened by deep-basement office redevelopment in the City of London (Ottaway 2005, 11), the financial district that is also the historic (Roman) centre of London.

In the second half of the 1980s, the DUA encouraged developers to fund excavations prior to construction; the alternative was to wait for government funding, and created a business decision for the developers - was it more cost-effective to pay for the work, or to accept the losses that delaying the project would bring?

Paying to undertake the work was clearly the preferred option, and by the end of the 1980 s virtually all excavations in the City of London were funded directly by the developers (Spence 1993, 24).

On the back of this developer funding, the DUA (and its sister within the Museum of London, the Department of Greater London Archaeology, which undertook work outside the defined City of London core) both grew rapidly, and by the end of the 1980s, 'At the 
height of the property boom, in 1989, the Museum of London's Departments of Urban and Greater London Archaeology were employing well over 400 archaeologists' (CBA 1991, 1).

From the 1990s onwards, the overwhelming majority of archaeologists working in the UK have been working in commercial, development-led and developer-funded archaeology. The work these people do is ultimately for the public benefit. They do not work for the public - they work for the private companies that employ them, who are contracted to do this by commercial clients, and it is those clients that deliver public benefit by financing the archaeological work.

So commercially-funded, development-led archaeology is not a new concept in the UK, it is not a challenge to orthodox models - it is, in Raymond Williams' (1977, chapter 8) terms, the dominant culture. By 2007, 93\% of archaeological investigations in England were development-led, public benefit projects delivered by commercial companies (Aitchison 2009, 661).

The case studies presented here highlight the work of members of FAME, the Federation of Archaeological Managers and Employers. FAME is the trade association for organisations like MOLA, Oxford Archaeology and Headland Archaeology, who will feature in the case studies, and that carry out commercial, development-led archaeological work in the UK and the Republic of Ireland. The association has existed since 1975, supporting commercial businesses for nearly half a century. And FAME's Vision Statement sets out that the association wants:

'To strive for a business environment where archaeological organizations can operate safely and sustainably, the well-being of employees is prioritised and archaeologists feel empowered to build careers and expertise, so that collectively we can conserve and advance knowledge of the past for the benefit of society' (FAME $\underline{\text { n.d. }}$ )

The last phrase is key - 'conserve and advance knowledge of the past for the benefit of society'. This may be a business association, but it is very much focused on delivering public value.

The largest of FAME's member organisations such as MOLA, Oxford Archaeology, also Wessex Archaeology and Cotswold Archaeology, each employ hundreds of archaeologists, and in both 2018 and 2019 each of these four organisations were paid more than $€ 12 \mathrm{~m}(£ 10 \mathrm{~m})$ by clients to undertake archaeological work (charitable or trading activity figures extracted from Charity Commission 2019a; 2019b; 2019c; 2019d).

While all of these organisations are constituted as commercial, limited companies, they are simultaneously charities - bodies that are given certain dispensations by the government because they deliver real, visible public benefits and that cannot distribute profits, to owners or shareholders. Any surplus (it can't be called profit) that these companies produce must either be reinvested in the company or given away to other 'good causes'.

Furthermore, FAME members work in partnership with local government archaeological advisers (whose association is ALGAO, the Association of Local Government Archaeology Officers) who ensure that every project aligns with public benefit requirements, and in partnership with their clients. Every commercial archaeology 
project is a partnership project and every commercial archaeology project is a public benefit project.

How commercial practice delivers public benefit is elaborated here through three case studies, focusing on aspects that could be transferable, with the overarching principles behind the case studies specifically highlighted.

\section{A14 Cambridge to Huntingdon Improvement Scheme}

The first case study is of the archaeological work on the A14 road between Cambridge and Huntingdon in the east of England. Between 2016 and 2020, 34km of road was upgraded and a new bypass was built by Highways England, a government-owned company that is responsible for the operation, management and improvement of major roads and motorways in England.

The archaeological work on the A14 Cambridge to Huntingdon improvement scheme was commissioned by Highways England, the client, who worked with Cambridgeshire County Council's archaeology service - the local curator (ALGAO member) - and two archaeological contractors - companies - Headland Archaeology and MOLA, who worked through a joint venture instrument MOLA Headland Infrastructure. Figure 2 shows the excavation of a possible henge monument immediately beside the A14.

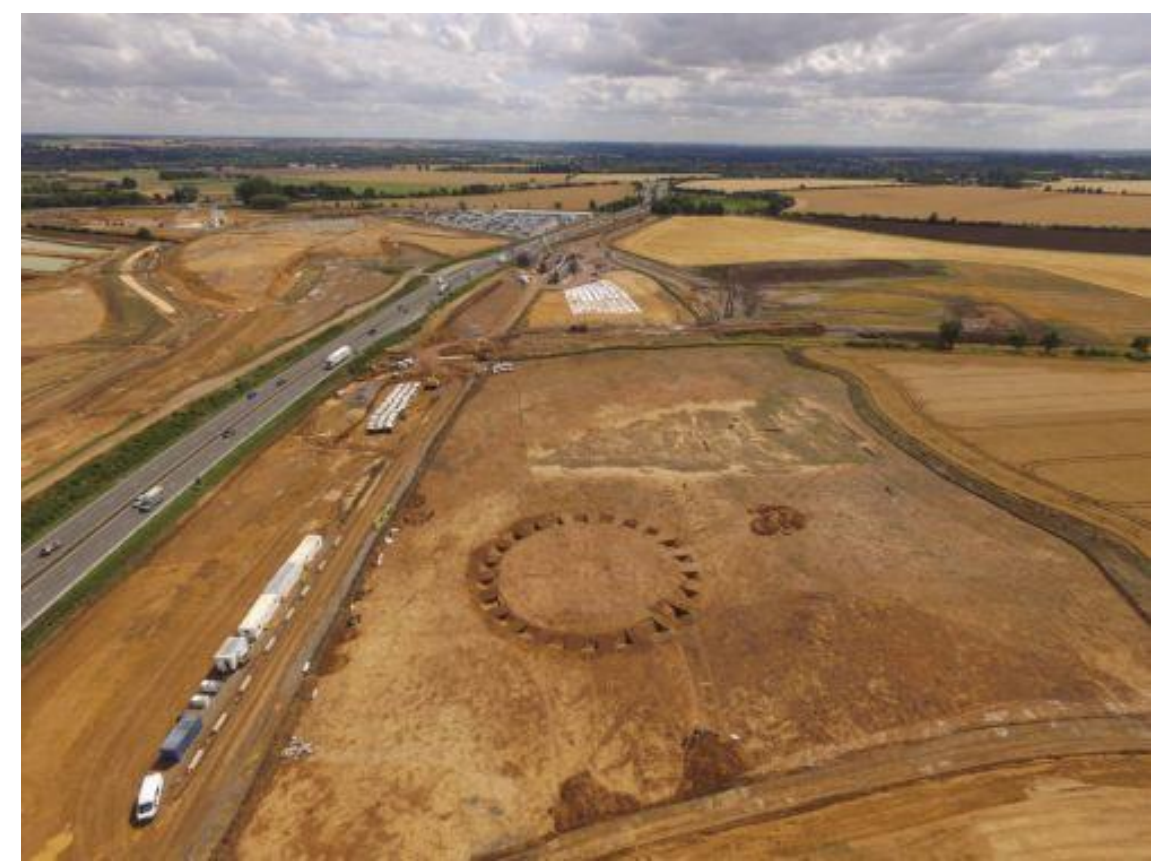

Figure 2: Bronze Age monument 200, originally assumed to be a henge, during excavations for the A14 Cambridge to Huntingdon improvement scheme beside the A1, Cambridgeshire. Location: https://www.google.com/maps/@52.2827237,-$\underline{0.280687,11.19 z}$ Image: MOLA Headland Infrastructure for Highways England 2018.

The A14 Cambridge to Huntingdon improvement scheme was planned to deliver public benefit, as the road is considered to be a '... vital road transport corridor between the 
West Midlands and East Anglia, and is of local, regional, national and international significance. The section of the route between Huntingdon and Cambridge carries a high level of commuter as well as long-distance traffic and provides a strategic link between the A1 and the M11 motorway. The A14 carries around 85,000 vehicles per day; $26 \%$ of this is HGV traffic (against the national average of $10 \%$ ). It is frequently congested and traffic is often disrupted by breakdowns, accidents and roadworks' (Highways England n.d.). On the A14 Cambridge to Huntingdon improvement scheme, prior to and then during the planning and environmental impact assessment stages of the project, the enormous archaeological potential of the landscape that the road runs through was recognised.

The earliest fieldwork - geophysical prospection - took place in 2009, seven years before construction work began, and subsequently over 350ha were excavated in 40 separate interventions. This has been the largest archaeological investigation funded by Highways England (both in terms of money spent and the numbers of archaeologists working on the project - 250 individuals at peak) (Highways England 2018).

With archaeological work forming such an important component of projects like the A14 Cambridge to Huntingdon, the commercial archaeology firms have to play a major role in project design and delivery. They work with the clients as partners, not as generic subcontractors brought in to deal with a technical issue.

The project delivers the public benefits identified by Highways England through improving communications and environmental qualities. Archaeologically, the project has led to significant development in understanding the region's past, from the Palaeolithic onwards and particularly relating to the later Iron Age-Roman-early medieval. Methodologically, this project has led to new approaches in the delivery of complex projects, as the archaeological partners have improved the quality and efficiency of their work and abilities to work together (Coleman 2019).

This project has been funded by the state, through a government-owned company as client, advised by local government archaeologists, and with the two contractors forming a joint venture to deliver work that has facilitated the client's demonstration of clear public benefit.

The key outcomes have been:

- advances in public understanding

- development of improved methodologies

The overarching principle at work here is

- the client's legal obligations benefit both the public and professional archaeology

\section{Crossrail}

The second case study is Crossrail, a project that was been described as 'Europe's largest infrastructure project' (Crossrail 2018). This is a new railway line extending across central London and continuing beyond the urban core to Berkshire in the west and Essex in the east. 
Crossrail is the name of both the project and the company delivering it; the Crossrail company is completely owned by TfL (Transport for London), the local government body responsible for the transport system in Greater London. Work began in 2009, and it is anticipated the line will start to open in 2022 (Duffy 2020).

A lot of archaeological work was generated by Crossrail and delivered by FAME members Oxford Archaeology (working with international consulting engineers Ramboll) and MOLA; the scale of the project is considerable, with $118 \mathrm{~km}$ of rail line, including $42 \mathrm{~km}$ of tunnels, eight new stations and upgrading 28 existing stations. This resulted in over 40 archaeological sites being investigated between 2009 and 2015

(Dempsey 2017), including the excavation of a Roman road, ditches and burials beneath a later, post-medieval burial ground (MOLA 2019) beneath the main ticketing hall of Liverpool Street Station as shown in Figure 3.

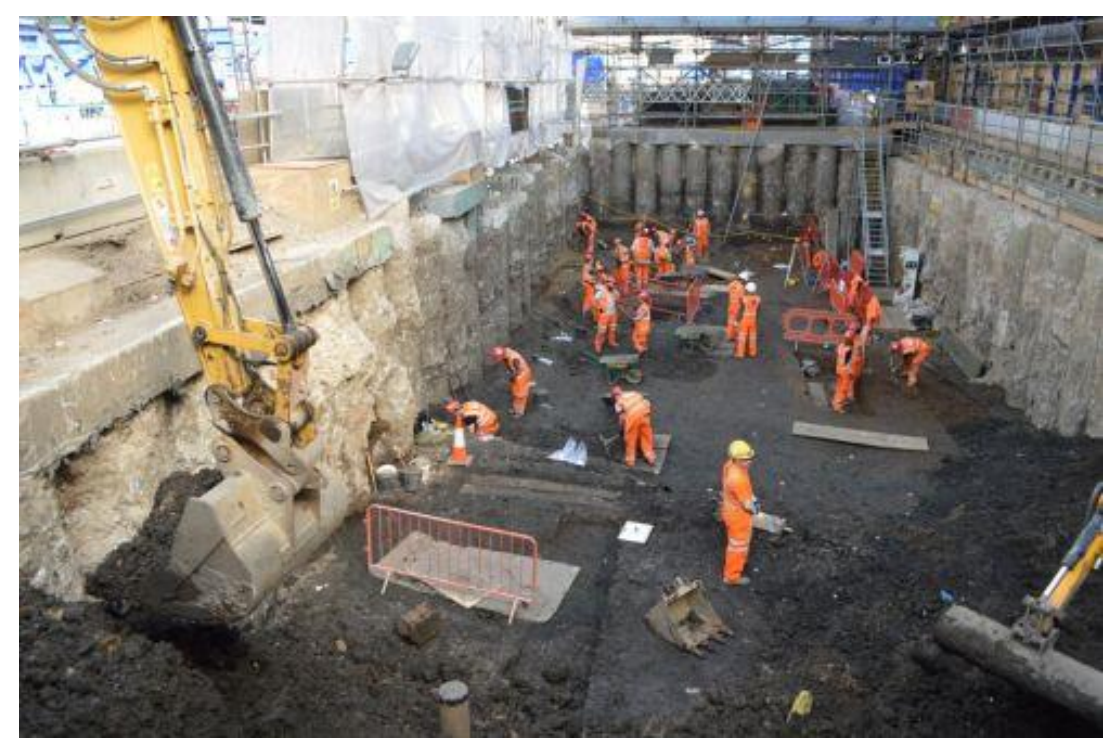

Figure 3: Crossrail archaeology excavations. Photo by Matt Brown (CC BY 2.0). Location: https://www.google.com/maps/place/Liverpool+Street+Station/@51.5187516,$0.0836261,17 z$

Applied commercial archaeology has only been able to develop and exist where clients (or client organisations) are willing to pay for it to be undertaken. And, realistically, this has only been achieved through legislative compulsion, and now can only be delivered through partnership working.

Commercial archaeology in the UK is a partnership process, exemplified by Crossrail. Commercial archaeology in the UK is delivering public benefit through partnerships between developers, FAME members and ALGAO advisors to local government.

The archaeological contractors and consultants had to work very closely with their client partners to ensure full integration with the construction programme, on occasion having '... to come up with solutions to accelerate the work, including increased resources, extended hours, and carefully agreed work stages to allow construction and archaeology to continue concurrently' (Jay Carver, quoted in Excell 2014).

Projects like Crossrail are megaprojects - infrastructure developments of such significant scale that they are strategically important at a national level. In addition to the 
public value of project delivery, these projects also look to improve quality standards and competences within the construction, and construction-related sectors - such as applied archaeology.

And to this end, Crossrail formalised its intention to collate and disseminate 'good practice, innovation and lessons learned from the Crossrail programme aimed at raising the bar in industry' (Crossrail $\underline{\text { n.d. }}$.) through the creation of a Crossrail Learning Legacy.

This approach means the work '.... contributes to an overall body of knowledge on major construction projects' (Crossrail n.d. $)$. It aims to share:

- 'Knowledge and insight gained during the lifetime of the Programme that may be of benefit to future projects and programmes

- Documents and templates that have been used successfully on the Programme that can be "pinched with pride" by other projects

- Datasets that can inform future research projects' (Crossrail n.d.)

This involved contributions from the archaeological partners in the project, in terms of methodological developments for archaeological practice but also to help engineering and construction partners work more effectively with archaeologists and vice versa.

This Crossrail learning legacy built upon the work previously undertaken for the London Olympics of 2012 (London 2012 n.d.). The creation of Learning Legacies has become accepted practice on megaprojects, and this approach is being emulated by Tideway (a major expansion to London's sewer network) (Tideway 2017), by the HighSpeed 2 railway connection between London and Birmingham (HS2 2018) and was planned for an intended expansion of Heathrow airport (Heathrow Skills Taskforce 2018).

The underlying key principle here is:

- The importance for public value created by the ability of the archaeologists to develop and maintain a very close working relationship with the construction and engineering teams they were working alongside.

The key outcome

- Crossrail learning legacy, benefiting the public and all sectors working together on this and future major infrastructure projects

Commercialisation does not automatically lead to applied archaeology always being done for the lowest price. Price and cost are two different things, and it is cost rather than price that matters to developers. Developers perceive cost in terms of any negative outcomes, including high prices but also taking into account factors such as delays and reputational damage (Blockley 1995, 111-12). This means that the cheapest price quoted might not always equate to the lowest cost to the developer. Furthermore, while there might be occasions when the would-be developer is presented with a choice between paying for work to be done quickly and professionally by a commercial company, or for it to be undertaken over a much longer period by well-meaning volunteers, the longer a site is left undeveloped the more this costs the developer (CgMs 2001). 


\section{Bloomberg}

Risks of delays and reputational damage are particularly relevant in the final case study, Bloomberg London. This site is in the City of London, and here the archaeological work was delivered by one FAME member, MOLA.

The City of London - the financial district also known as 'the square mile', and not to be confused with the entirety of Greater London today, which extends across $1,572 \mathrm{~km}^{2}-$ is a discrete political entity that covers $2.9 \mathrm{~km}^{2}$ (1.12 square miles). Unlike other parts of London, where local government is through Borough Councils, the City of London is governed differently, under what it considers to be 'the oldest continuous municipal democracy' (City of London n.d.). In large part, the boundaries of the City of London are defined by the walls of Roman London (whether they are still visible above ground or not), and so Roman (and medieval) stratigraphy survived across most of the City until the advent of deep foundation skyscrapers in the second half of the 20th century (Biddle et al. 1973).

Archaeological work in the City of London has been of enormous significance for the development of practice and public benefit, as the coincidence of economic demand (at the centre of the primary financial district) and of well-preserved, deeply stratified archaeological materials has resulted in a great deal of high-quality, commercially funded archaeological work being undertaken.

Bloomberg London is the European headquarters of Bloomberg L.P., an international financial analysis and information company, which is strongly identified with its eponymous majority shareholder, Michael Bloomberg. The site was bought by Bloomberg L.P. in 2010 and construction work was completed in 2017 (Architects Journal 2017).

Previously, Bucklersbury House, a 1957 modernist office block (in its day the tallest office building in the City of London; Salih 2017) had occupied the site - which had been bombed in 1940-41. When the site was cleared to prepare for the 1950s construction, Roman deposits, including the site of a Temple of Mithras - a Mithraeum - were exposed - and this led to enormous public interest. The site was excavated (at public expense, as was universally the case in the 1950s) and the Mithraeum was reconstructed nearby (Grimes 1968).

The demolition of the 1950s structure revealed there were still significant deposits surviving beneath its footings, and MOLA were commissioned to undertake the excavation (as shown in Figure 4) - and also to contribute to the development of the interpretative museum on site and the relocation of the reconstructed Mithraeum to very close to its original position (it is slightly offset to preserve some walling excavated in the 1950s that had not been relocated) in a publicly accessible exhibition space - London Mithraeum Bloomberg SPACE - beneath the Bloomberg building (MOLA n.d.). 


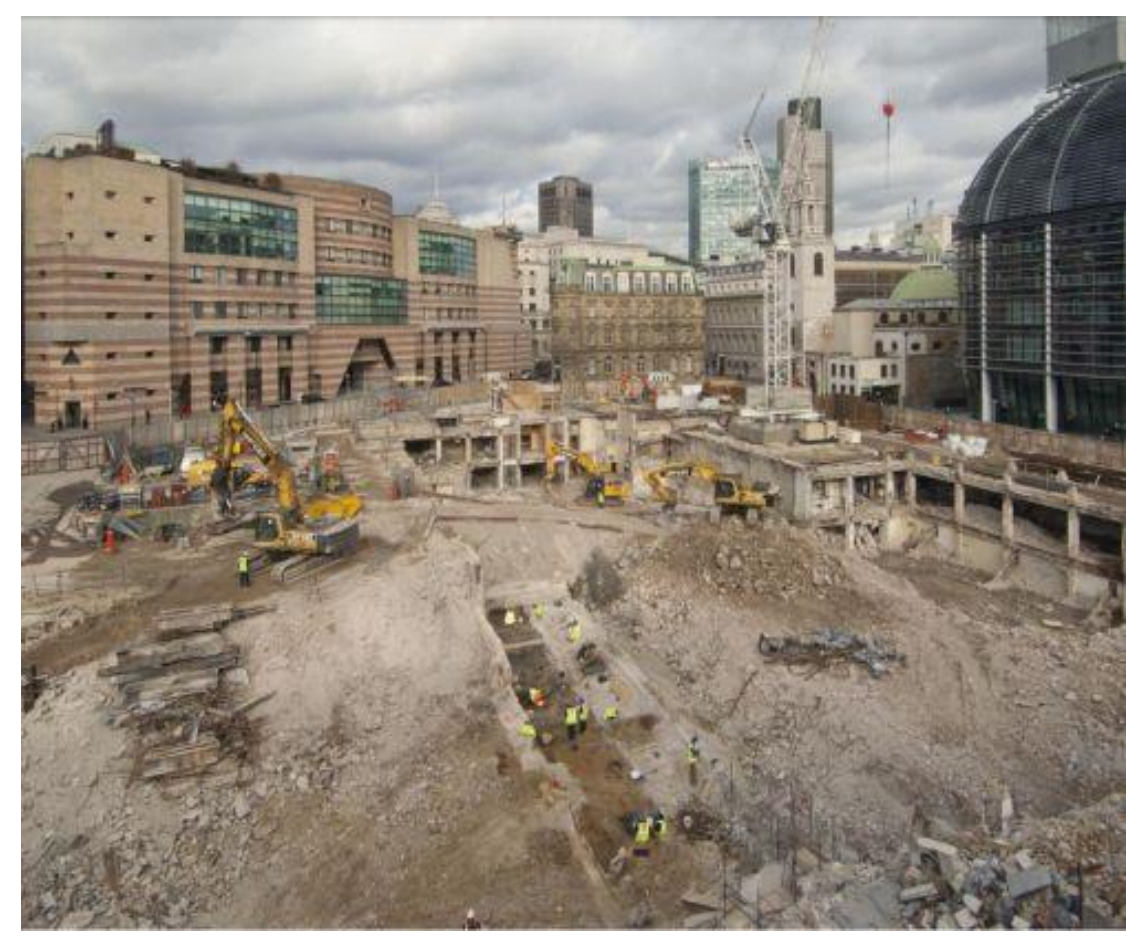

Figure 4: Bloomberg archaeology excavation in progress at the Bloomberg site in 2012, looking north, with 1 Poultry to the left and St Stephen Walbrook church to the right of the site. Image: MOLA for Bloomberg L.P.

Location: https://www.google.com/maps/@51.5126328,-0.0931317,17z

In two of these three examples, the client is the project - and the total association of client with project is the key point to be taken from the Bloomberg project.

Part of the development is a free to visit museum, combining the reconstruction with displays of artefacts and contemporary art. The archaeological work had to be done for the new building to be permitted, but the outcome was very public focused - as well as the London Mithraeum Bloomberg SPACE, public art celebrates the Walbrook, the 'lost' stream (now culverted underground) that the Mithraeum stood beside (King 2017).

The public benefits are strongly associated with Bloomberg L.P., and with its owner who wants to be seen as doing things that benefit the public. Michael Bloomberg is a politician, but one who also politics on behalf of his organisation - working to make it publicly trusted and popular (Bloomberg 2019). Public benefit can be private benefit too. Archaeological work for a private client results in public benefit - when the work is a partnership that has public benefit as one of its defined goals.

When the client is either a public body, or directly funded by the public purse, it can paradoxically be harder to demonstrate public benefit from archaeological partnership work; Michael Bloomberg and Bloomberg L.P. were never going to be shy about the reasons for their work, or shy about their desire to showcase the public benefit of it.

The underlying key principle here is:

- Private clients want to be associated with and recognised for the projects they are funding 
The key outcome

- When clients are seen as partners in creating public benefit, they will actively support this.

\section{Conclusions}

Archaeological work does not take place in a policy, or economic, vacuum. There has to be an economic need for archaeological work to take place, and the economic need has to be structured by political policy. But as archaeological deposits are fundamentally economically valueless, how can there be an economic need, a market for commercial practice, and how can it be to the public benefit that there is?

When archaeological remains are treated as environmental assets, then the theory and practice of environmental economics can be applied to find ways to calculate archaeology's economic value, because having an understanding and knowledge of these environmental assets can have value (Carman et al. 1999, 145). This has meant that a market for archaeological knowledge has developed - the clients of archaeologists will pay for archaeological fieldwork and analysis that transforms valueless deposits into knowledge that the clients can then use - often to demonstrate that they have complied with conditions placed upon them by regulators.

Without legislative underpinning, no-one would pay for archaeological remains to be investigated - and the relevant legislation will always refer to the social, cultural or environmental value (not the financial value) of the archaeological remains, which then present the raison d'être for investigation as a form of mitigation leading to the positive protection and management of the environmental resource. This has been exemplified in the UK, where state agencies, museums and universities do still undertake some fieldwork - but they have become minor players. Even MOLA - once an acronym for Museum of London Archaeology - is no longer part of that museum, but a separate, standalone organisation (MOLA 2011).

In the UK, political, social and economic norms have meant that commercial companies have been allowed to flourish in this environment. The client commissions a company, for whom the archaeologists work. Archaeologists are not directly employed by clients such as Highways England, but by archaeological companies who then work in partnership with their clients. Oxford Archaeology (who also worked directly with Ramboll, international consulting engineers) and MOLA, two of the largest companies in UK archaeology, undertook the archaeological work for Crossrail. MOLA again worked in partnership with Bloomberg L.P. to carry out the work that resulted in public benefit at the Bloomberg SPACE, and MOLA Headland Infrastructure were Highways England's partners on the A14 Cambridge to Huntingdon improvement scheme.

\section{Postscript}

Scotland's Archaeology Strategy (Scottish Strategic Advisory Committee 2016) (Figure 5 ) is an ongoing component of a decade of political consideration about the past, and its multiple values. It is a light-touch policy document, curated but not owned by the national heritage agency (Historic Environment Scotland) - and this has been welcomed by the 
commercial, applied archaeology sector. There are only four references to 'commercial archaeology' in the 28-page document; one is in a quote from Tim Holden, a director of a company that is a member of FAME, appreciating the backing for training that the Strategy will provide, and the other is from FAME itself, welcoming and supporting the Strategy.

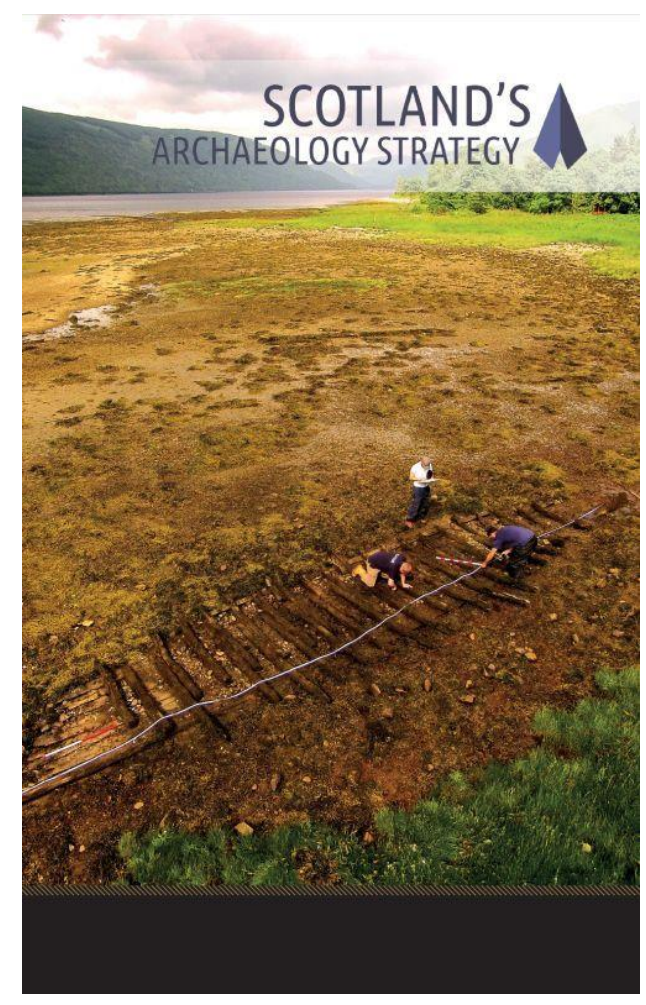

Figure 5: The front cover of Scotland's Archaeology Strategy. Historic vessel recording by maritime archaeologists at Loch Fyne 2015. Photo by Jonathan Benjamin. Location: https://www.google.com/maps/@56.2585179,-4.9522857,13.71z

While the cultural economy is being protected through environmental economic models, stemming largely from the concept of sustainable development as established by the UN in 'Our Common Future' - the 1987 report of the Brundtland Commission - commercial archaeology in the UK no longer operates under the concept of the 'Polluter Pays Principle'. That was a legacy of environmental economic theory that underpinned the earliest legislation and guidance, and is an assumption that the requirement to fund archaeological work is seen as a (legal) 'remedy' for the consequences of economic development.

There are no references to 'polluters' in Scotland's Archaeology Strategy. This is a policy document that recognises that developers are delivering public benefits, and archaeologists are working in partnership with them.

The key principle is: politics frame responses to economic and financial pressures. And so the ultimate outcome is: appropriate political handling (both the informal politics of liaison with client-partners, and political decision-making at local, national and European levels) leads to better opportunities for archaeology to deliver public benefit.

This will, by its very nature, be a continuous and ongoing process. Political priorities change, and so that political 'handling' has to continue to be undertaken, at every level. 
A series of political announcements in June and July 2020 (ARLA 2020) that revealed the UK government's intention to reform the planning system in England (Johnson 2020, underpinned by Airey 2020), prompted the Chair of FAME and the leaders of six other archaeological sector representative bodies to write to the Prime Minister reminding the policy makers of archaeology's place in delivering sustainable development through the planning system, and that this was not an area in need of reform (Hinton et al. 2020). The letter made reference to the fact that archaeology is not being cited as reason for major delays by developers (Cornerstone Projects 2017), nor that it has been identified as a factor that contributes to the 'significant gap between housing completions and the amount of land allocated or permissioned in areas of high housing demand, and make recommendations for closing it' (build-out rates) (Letwin 2018), and that it transfers cost away from the public to do this (Rocks-Macqueen and Lewis 2019, 16). The Prime Minister's Office acknowledged receipt of this letter, but did not reply to the authors. 